\title{
Manajemen Laba dan Nilai Perusahaan (Studi Empiris pada Perusahaan Manufaktur di Bursa Efek Indonesia)
}

\author{
I Gusti Bagus Indra Kusuma ${ }^{1}$ \\ Fakultas Ekonomi dan Bisnis \\ Universitas Udayana, Indonesia
}

\author{
I Made Mertha ${ }^{2}$ \\ Fakultas Ekonomi dan Bisnis \\ Universitas Udayana, Indonesia
}

Surel : indrakusumaigst97@gmail.com

\section{ABSTRAK}

Tujuan penelitian ini adalah untuk mengetahui pengaruh manajemen laba dengan pola income increasing dan income decreasing terhadap nilai perusahaan pada perusahaan manufaktur yang terdaftar di Bursa Efek Indonesia tahun 20142018. Populasi penelitian ini berjumlah 167 perusahaan. Sampel berjumlah 105 yang dipilih menggunakan teknik purposive sampling. Total pengamatan selama 5 tahun menjadi 525 amatan, kemudian dibagi menjadi dua kelompok, yaitu 472 pengamatan untuk manajemen laba income increasing dan 53 pengamatan untuk manajemen laba income decreasing. Penelitian ini menggunakan teknik analisis regresi linear sederhana. Hasil pengujian menunjukkan bahwa variabel manajemen labaincome increasing tidak berpengaruh terhadap nilai perusahaan, sedangkan manajemen laba income decreasing berpengaruh negatif terhadap nilai perusahaan.

Kata Kunci: Nilai Perusahaan; Manajemen Laba; Income Increasing; Income Decreasing.

\section{Profit Management and Firm Value (Empirical Study on Manufacturing Companies on the Indonesian Stock Exchange)}

\begin{abstract}
The purpose of this study is to determine the effect of earnings management with income increasing and income decreasing patterns on firm value in manufacturing companies listed on the Indonesia Stock Exchange in 2014-2018. The population of this research are 167 companies. A total of 105 samples are selected using a purposive sampling technique. Total observations over the 5 years to 525 observations, then divided into two groups, 472 observations for increasing income management and 53 observations for decreasing earnings management. This study uses a simple linear regression analysis technique. The test results show that income increasing earnings management variable does not affect the value of the company, while earnings decreasing earnings management has a negative effect on firm value.
\end{abstract}

Keywords: Firm Value; Earnings Management; Income Increasing; Income Decreasing.

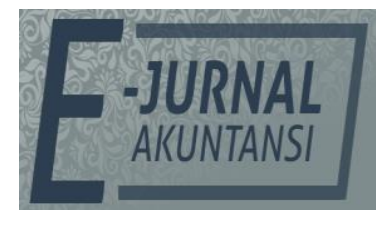

e-ISSN 2302-8556

Vol. 31 No. 1

Denpasar, Januari 2021

Hal. 1821-196

DOI:

10.24843/EJA.2021.v31.i01.p14

PENGUTIPAN:

Kusuma, I G.B.I., \& Mertha, I M. (2021). Manajemen Laba dan Nilai Perusahaan (Studi Empiris pada Perusahaan Manufaktur di Bursa Efek Indoensia). E-Jurnal Akuntansi, 31(1), 182-196

RIWAYAT ARTIKEL: Artikel Masuk: 7 Juli 2020 Artikel Diterima: 4 Januari 2021

Artikel dapat diakses : https://ojs.unud.ac.id/index.php/Akuntansi/index 


\section{PENDAHULUAN}

Suatu perusahaan dibangun untuk memenuhi kebutuhan manusia atau para konsumen dalam menjalani aktivitasnya sehari-hari, dan perusahaan mendapatkan keuntungan atau laba sebagai imbalannya. Selain itu, perusahaan juga beroperasi untuk meningkatkan nilai perusahaan(Sintyana \& Artini, 2018). Nilai perusahaan adalah gambaran dari kondisi suatu perusahaan selama satu periode tertentu(Rahayu \& Sari, 2018). Nilai perusahaan mencerminkan baik atau buruknya operasional dalam suatu perusahaan, sehingga hal ini juga mempengaruhi kemakmuran para pemegang saham(Suhadak et al., 2019). Tingkat laba merupakan salah satu faktor penentu nilai perusahaan karena tingkat laba dalam laporan keuangan tahunan perusahaan pada umumnya menggambarkan hasil atas kinerja operasional perusahaan selama satu periode (Puspitaningtyas, 2017). Ketika laba perusahaan meningkat, hal ini akan memengaruhi respon pasar terhadap nilai atau harga saham perusahaan sehingga harga saham pun meningkat. Harga saham yang meningkat ini mencerminkan kemakmuran para pemegang saham atau dapat dikatakan bahwa para pemegang saham mendapatkan keuntungan dari kenaikan harga saham tersebut, "karena harga saham merupakan hasil penilaian dalam keputusan investasi, pendanaan, dan kebijakan dividen.

Penelitian ini mencoba meneliti nilai perusahaan dengan pendekatan nilai perusahaan dengan menggunakan rasio Tobin's $Q$ karena penghitungan rasio Tobin's $Q$ lebih rasional mengingat unsur-unsur kewajiban juga dimasukkan sebagai dasar penghitungan. Rata - rata nilai perusahaan (yang diproksikan dengan Tobin's Q) pada perusahaan manufaktur yang terdaftar di BEI berturutturut selama periode lima tahun (dari tahun 2014 sampai 2018). Selama periode tersebut rata-rata nilai perusahaan pada perusahaan manufaktur mengalami fluktuasi. Mulai pada tahun 2014 sampai 2015, nilai perusahaan mengalami penurunan, namun pada tahun 2015 hingga tahun 2017 nilai perusahaan manufaktur mengalami kenaikan secara bertahap yang memuncak pada tahun 2017. Kemudian pada tahun 2017 hingga tahun 2018 mengalami penurunan yang cukup signifikan. Fenomena ini menunjukkan bahwa "fluktuatifnya rata-rata nilai perusahaan kemungkinan diakibatkan oleh adanya praktik manajemen laba."

Para stakeholders menggunakan informasi-informasi yang terdapat di dalam laporan keuangan sebagai bahan pertimbangan untuk pengambilan keputusan bisnis (Ježovita, 2015). Sebagai contoh, para investor umumnya akan menganalisis komponen-komponen laporan keuangan sebelum memutuskan untuk berinvestasi di suatu perusahaan. Salah satu komponen penting yang sering menjadi pertimbangan para investor adalah laba. Laba yang dipublikasikan dalam laporan keuangan mencerminkan kinerja perusahaan dalam satu periode akuntansi (Nursya'adah, 2020). Hal ini selanjutnya akan memengaruhi respon pasar terhadap harga saham perusahaan. Para investor melihat prospek perusahaan melalui laporan keuangan. Jika prospek perusahaan dianggap memenuhi kriteria maka investor akan berminat untuk berinvestasi pada perusahaan tersebut dengan membeli sahamnya. Ketika harga saham tersebut meningkat karena kualitas kinerja perusahaan meningkat yang 
tercermin pada laporan keuangan, maka kesejahteraan para pemegang saham atau investor pun menjadi meningkat.

Informasi yang diterima oleh para stakeholders termasuk para pemilik perusahaan melalui laporan keuangan merupakan isyarat atau sinyal yang diberikan oleh manajer perusahaan. Pemberian sinyal yang dilakukan oleh manajer bertujuan untuk mengurangi asimetri informasi. Misalnya, "informasi laba yang meningkat pada laporan keuangan merupakan sinyal good news bagi para stakeholders." Kemudian berdasarkan informasi tersebut, investor maupun para stakeholders akan menilai kinerja perusahaan dan mempertimbangkan keputusan. Begitu pula jika informasi laba yang dilaporkan pada laporan keuangan menurun. Hal tersebut mengindikasikan sinyal bad news bagi para stakeholders.

Salah satu cara manajer untuk memengaruhi tingkat laba yang dilaporkan adalah dengan melakukan praktik manajemen laba. Manajemen laba berkaitan dengan pemilihan metode akuntansi yang dilakukan oleh manajer dalam pelaporan keuangan untuk menaikkan laba atau menurunkan laba agar sesuai dengan kepentingan manajer atau kepentingan perusahaan dan pihak-pihak yang terlibat dalam kontrak (Kanakriyah et al., 2017). Metode akuntansi berbasis akrual dianggap lebih tepat dalam menyediakan informasi keuangan (Dalimunthe, 2016). Sebab, metode akrual memberikan gambaran yang lebih jelas mengenai kondisi keuangan perusahaan. Namun, metode akrual sangat rentan dimanipulasi karena akun-akun akrual umumnya bersifat nominal dan berdasarkan estimasi-estimasi. Hal ini yang dimanfaatkan oleh manajer untuk memaksimalkan kepentingan pribadinya. Ada dua perspektif dalam memahami perilaku manajer atas praktik manajemen laba, yaitu opportunistic behavior perspective dan efficient contracting perspective (Ghazali et al., 2015).

Penjelasan tersebut sejalan dengan perspektif teori agensi yang dapat menjelaskan perilaku manajer atas praktik manajemen laba. Hubungan kerja antara pemilik perusahaan atau principal dengan manajer atau agent dalam sebuah organisasi cenderung menimbulkan konflik keagenan (Panda \& Leepsa, 2017). Manajer seringkali memiliki kepentingan yang berbeda dengan pemilik perusahaan. Teori ini mengatakan bahwa para pemilik perusahaan menginginkan kemakmuran yang berasal dari bisnis yang mereka jalankan, sedangkan manajer ingin memaksimalkan kepentingan pribadinya. Salah satu cara manajer agar dapat memaksimalkan kepentingan pribadinya adalah dengan melakukan praktik manajemen laba. Praktik manajemen labadapat dilakukan oleh manajer karena adanya asimetri informasi antara manajer dan pemilik perusahaan. Manajer perusahaan memiliki informasi yang lebih detail mengenai operasional perusahaan daripada pemilik perusahaan. Maka dapat dikatakan bahwa konflik keagenan adalah pemicu adanya perilaku opportunistic manajer yang membuat laba yang dilaporkan menjadi semu, sehingga menyebabkan nilai perusahaan berkurang di masa yang akan datang.

Fenomena manajemen laba sering terjadi di dunia nyata saat ini dan menimbulkan masalah serta kerugian yang dirasakan berbagai pihak. Manajemen laba pernah terjadi pada perusahaan manufaktur yaitu PT Tiga Pilar Sejahtera Food Tbk Setiap usaha tentu memiliki tujuan yang mendasar yaitu mendapatkan keuntungan berupa laba. Laba merupakan selisih antara 
pendapatan yang diperoleh suatu perusahaan pada suatu periode dengan bebanbeban yang terjadi selama periode tersebut. Manajemen PT Tiga Pilar Sejahtera Food Tbk sebagai pengelola perusahaan tentu berusaha untuk memajukan perusahaan dalam pencapaian laba melalui kebijakan-kebijakan akuntansinya yang tentunya semakin tahun akan semakin bertambah sehingga baik kinerja manajemen atau perusahaan dapat dinilai baik.

Tabel 1. Laba Bersih Setelah Pajak dan Closing Price Tahun 2006-2017

\begin{tabular}{|c|c|c|c|c|c|c|c|c|}
\hline Tahun & \multicolumn{2}{|c|}{$\begin{array}{l}\text { Laba Bersih setelah } \\
\text { Pajak (dalam jutaan } \\
\text { rupiah) }\end{array}$} & \multicolumn{2}{|c|}{$\begin{array}{l}\text { Harga Saham } \\
\text { (Closing Price) }\end{array}$} & \multicolumn{2}{|c|}{$\begin{array}{c}\text { Harga } \\
\text { Saham } \\
\text { Tertinggi }\end{array}$} & \multicolumn{2}{|c|}{$\begin{array}{c}\text { Harga } \\
\text { Saham } \\
\text { Terendah }\end{array}$} \\
\hline 2006 & $\mathrm{Rp}$ & 132 & $\mathrm{Rp}$ & 151 & & 151 & $\mathrm{Rp}$ & 147 \\
\hline 2007 & $\mathrm{Rp}$ & $15.767 \uparrow$ & $\mathrm{Rp}$ & $649 \uparrow$ & $\mathrm{Rp}$ & 649 & $\mathrm{Rp}$ & 614 \\
\hline 2008 & $\mathrm{Rp}$ & $37.485 \uparrow$ & $\mathrm{Rp}$ & $389 \downarrow$ & $\mathrm{Rp}$ & 389 & $\mathrm{Rp}$ & 343 \\
\hline 2009 & $\mathrm{Rp}$ & $37.823 \uparrow$ & $\mathrm{Rp}$ & $329 \downarrow$ & $\mathrm{Rp}$ & 329 & $\mathrm{Rp}$ & 311 \\
\hline 2010 & $\mathrm{Rp}$ & $75.857 \uparrow$ & $\mathrm{Rp}$ & $713 \uparrow$ & $\mathrm{Rp}$ & 722 & $\mathrm{Rp}$ & 686 \\
\hline 2011 & $\mathrm{Rp}$ & $126.906 \uparrow$ & $\mathrm{Rp}$ & $495 \downarrow$ & $\mathrm{Rp}$ & 495 & $\mathrm{Rp}$ & 485 \\
\hline 2012 & $\mathrm{Rp}$ & $211.197 \uparrow$ & $\mathrm{Rp}$ & $1.080 \uparrow$ & $\mathrm{Rp}$ & .080 & $\mathrm{Rp}$ & 1.000 \\
\hline 2013 & $\mathrm{Rp}$ & $310.394 \uparrow$ & $\mathrm{Rp}$ & $1.430 \uparrow$ & $\mathrm{Rp}$ & .450 & $\mathrm{Rp}$ & 1.420 \\
\hline 2014 & $\mathrm{Rp}$ & $331.702 \uparrow$ & Rp & $2.095 \uparrow$ & $\mathrm{Rp}$ & 2.100 & $\mathrm{Rp}$ & 2.080 \\
\hline 2015 & $\mathrm{Rp}$ & $323.441 \downarrow$ & $\mathrm{Rp}$ & $1.210 \downarrow$ & $\mathrm{Rp}$ & .230 & $\mathrm{Rp}$ & 1.205 \\
\hline 2016 & $\mathrm{Rp}$ & $593.475 \uparrow$ & $\mathrm{Rp}$ & $1.945 \uparrow$ & $\mathrm{Rp}$ & 2.020 & $\mathrm{Rp}$ & 1.945 \\
\hline 2017 & $\mathrm{Rp}$ & $(551.903) \downarrow$ & $\mathrm{Rp}$ & $476 \downarrow$ & $R p$ & 486 & $\mathrm{Rp}$ & 472 \\
\hline
\end{tabular}

Sumber: Data Penelitian, 2019

Laba perusahaan mengalami kenaikkan yang mengindikasikan bahwa kinerja perusahaan baik, akan tetapi terjadi ketidakseimbangan antara laba yang diperoleh dibandingkan dengan harga saham yang ada. Laba perusahaan akan menentukan nilai saham perusahaan bersangkutan yang berarti, pada saat laba perusahaan meningkat semestinya harga saham meningkat begitu juga sebaliknya saat laba perusahaan turun maka harga saham perusahaan juga ikut turun. Ketidakseimbangan ini terjadi pada tahun 2007 hingga tahun 2009, dimana laba yang diperoleh senilai Rp 15.767 juta naik menjadi Rp. 37.485 juta pada tahun 2008 dan naik menjadi Rp 37.823 juta pada tahun 2009, tetapi harga saham malah turun dari Rp 649 ke Rp 389 dan berakhir pada nilai Rp 329 pada tahun 2009. Hal yang sama terjadi juga pada tahun 2010 ke tahun 2011.

Apabila laba meningkat, secara teoritis harga saham juga akan meningkat. Semakin tinggi laba perusahaan, maka semakin tinggi pula harga saham perusahaan, dengan kata lain peningkatan maupun penurunan laba akan memengaruhi harga saham yang merupakan cerminan dari nilai "perusahaan. Ketidakseimbangan tersebut memberikan asumsi bahwa telah terjadi praktik manajemen laba yang dilakukan manajemen dengan menggunakan pola manajemen laba yang disebut sebagai Income Maximization

Kasus manajemen laba yang baru ini terjadi adalah kasus PT Tiga Pilar Sejahtera Food Tbk (AISA) yang diduga telah terjadi penggelembungan senilai Rp. 4 triliun oleh manajemen lama pada laporan keuangan perusahaan tahun 2017. Hasil Investigasi Berbasis Fakta yang dilakukan oleh PT Ernst \& Young Indonesia (EY) kepada manajemen baru AISA yang tertanggal 12 Maret 2019, dugaan penggelembungan ditengarai terjadi pada akun piutang usaha, persediaan, dan aset tetap Grup AISA. Laporan keuangan Tiga Pilar periode 
2017 yang diaudit oleh Kantor Akuntan Publik (KAP) RSM International dipersoalkan oleh manajemen baru yang mengambil alih perseroan pada Oktober 2018. Hasil investigasi terhadap laporan keuangan tersebut menyatakan bahwa adanya temuan terhadap dugaan penggelembungan pada pos akuntansi senilai Rp. 4 triliun serta beberapa dugaan lain.

Laporan keuangan PT Tiga Pilar Sejahtera Food Tbk tahun buku 2017 disajikan ulang pada tahun 2020, termasuk laporan keuangan 2018 dan 2019 yang ketika itu belum dilaporkan. Perusahaan membukukan rugi bersih $\operatorname{Rp} 5,23$ triliun sepanjang 2017, pada laporan keuangan yang telah di-restatement tersebut. Jumlah ini lebih besar $\operatorname{Rp} 4,68$ triliun dari laporan keuangan versi sebelumnya yang hanya rugi Rp 551,9 miliar. Hal ini membenarkan dugaan PT Ernst \& Young Indonesia dan membuktikan bahwa adanya praktik manajemen laba yang dilakukan oleh manajemen lama perusahaan tersebut, yaitu dengan cara menaikkan laba (menurunkan rugi) yang dilaporkan dari laba (rugi) yang sesungguhnya sehingga rugi yang dialami oleh perusahaan terlihat lebih kecil. Manajemen laba yang dilakukan oleh perusahaan ini bertujuan untuk menjaga nilai perusahaan sehingga tidak jatuh di mata para stakeholders, tetapi yang justru terjadi dalam kasus ini adalah perusahaan mengalami penurunan nilai perusahaan yang signifikan. BEI men-suspend saham AISA di harga Rp. 168 pada tanggal 6 Juli 2018 untuk melindungi para investor dari kerugian yang lebih besar.

Hasil penelitian Abbas (2018), Gill et al.(2015), Subanidjaet al.(2016) dan Susanto \& Christiawan (2016) menyatakan bahwa manajemen laba memiliki pengaruh yang positif pada nilai perusahaan. Sebaliknya, Wijaya \& Budiasih (2018), Oktavani \& Devie (2017), Yuniarti et al. (2017), Astiti \& Damayanthi (2018), Surifah (2017), dan Darmawan et al. (2019) menemukan hasil bahwa "manajemen laba memiliki pengaruh yang negatif pada nilai perusahaan". Penelitian yang dilakukan oleh Fahmi \& Prayoga (2018), Sunardi (2018), Susanto (2017), Ustman \& Ghofar (2016) dan Mawati et al. (2017) menemukan hasil bahwa "manajemen laba tidak memiliki pengaruh pada nilai perusahaan".

Hasil dari penelitian sebelumnya dapat diketahui bahwa masih belum adanya konsistensi pengaruh manajemen laba pada nilai perusahaan menjadi motivasi peneliti untuk melakukan penelitian kembali. Penelitian ini bermaksud membagi pengaruh manajemen laba ke dalam dua kelompok seperti yang pernah dilakukan pada penelitian Lesmana \& Sukartha (2017). Pengaruh manajemen laba dibagi menjadi dua kelompok, yaitu manajemen laba dengan cara income increasing dan kelompok manajemen laba dengan cara income decreasing pada nilai perusahaan.

Penelitian ini mencoba untuk menggunakan objek penelitian pada perusahaan manufaktur yang konsisten terdaftar di BEI dari tahun 2014 sampai 2018 dimana telah terjadi fluktuasi nilai perusahaan yang cukup signifikan. Perusahaan manufaktur dipilih sebagai lokasi penelitian karena perusahaan manufaktur memiliki cakupan lini produk yang lebih luas, yang memungkinkan manajemen laba bersifat lebih material dibandingkan dengan cakupan lini produk yang sempit dan perhitungan manajemen laba yang memang mencerminkan kondisi perusahaan manufaktur. Jumlah dari perusahaan 
manufaktur juga merupakan jumlah terbanyak yang terdaftar di BEI dibandingkan dengan jenis perusahaan lain.

Penelitian ini dilakukan berdasarkan hasil penelitian-penelitian terdahulu yang menujukkan hasil tidak konsisten mengenai hubungan antara manajemen laba dan nilai perusahaan, maka peneliti termotivasi untuk menguji kembali hubungan antar variabel tersebut. Berdasarkan latar belakang tersebut peneliti tertarik untuk melakukan penelitian lebih lanjut mengenai pengaruh manajemen laba terhadap nilai perusahaan. Mengacu pada latar belakang penelitian ini, maka dirumuskan tujuan untuk penelitian ini sebagai berikut: 1) Mengetahui pengaruh manajemen laba dengan pola income increasing terhadap nilai perusahaan increasing. 2) Mengetahui pengaruh manajemen laba dengan pola incomedecreasing terhadap nilai perusahaan decreasing. Secara sistematis, konsep penelitian yang digunakan pada penelitian ini dapat digambarkan sebagai berikut.

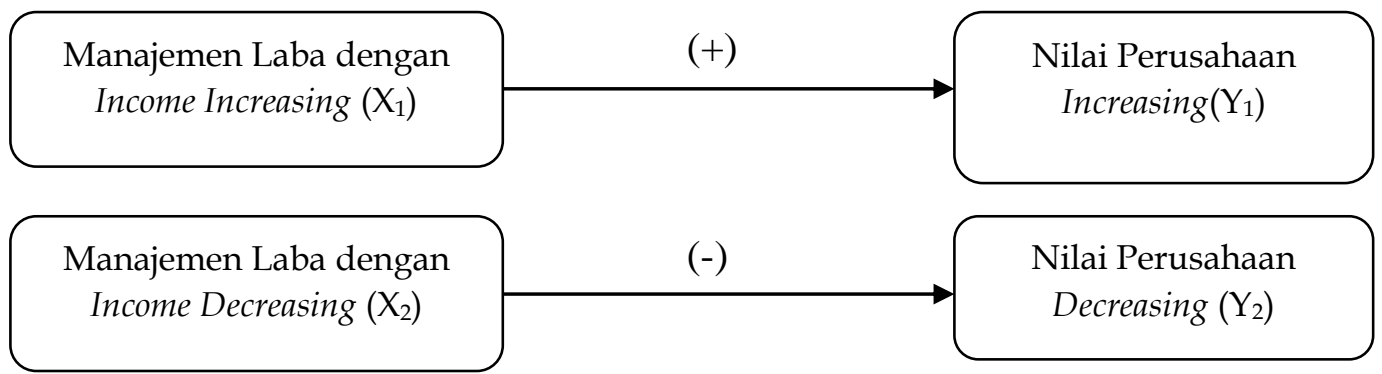

Sumber: Data Penelitian, 2019

\section{Gambar 1. Kerangka Konseptual}

Manajer melakukan manajemen laba dengan menaikkan laba yang dilaporkan, maka akan terdapat peningkatan kemakmuran pemegang saham. Hal tersebut merupakan sinyal baik (good news) bagi pemegang saham, sehingga akan merangsang reaksi pasar berupa peningkatan harga saham. Meningkatnya harga saham akan mempunyai dampak pada peningkatan nilai perusahaan. Penelitian Abbas (2018), Gill et al. (2015), Subanidjaet al. (2016), Susanto \& Christiawan (2016) membuktikan bahwa manajemen laba memiliki pengaruh yang positif pada nilai perusahaan. Penelitian Susanto \& Christiawan (2016) berhasil membuktikan bahwa manajamen laba, ukuran perusahaan berpengaruh positif signifikan terhadap nilai perusahaan. Hal ini berarti praktik manajemen laba dapat menaikan nilai perusahaan. Berdasarkan aspek-aspek tersebut, maka didapatkan hipotesis pertama dalam penelitian ini adalah sebagai berikut.

$\mathrm{H}_{1}$ : Manajemen laba dengan pola income increasing berpengaruh positif pada nilai perusahaanincreasing.

Ketika manajer mempraktikan manajemen laba dengan cara menurunkan laba yang dilaporkan untuk memperoleh keuntungan tertentu. Tentu ada hal yang memotivasi manajer untuk melakukan penurunan laba yaitu untuk mengurangi tingkat visibilitas perusahaan agar memperoleh kemudahan dan fasilitas dari pemerintah, untuk mengurangi pajak yang harus dibayar, dan untuk memaksimalkan bonus yang didapatkan pada periode mendatang. Teori keagenan menjelaskan bahwa ketika manajemen laba dilakukan yaitu melalui penurunan laba, maka akan terdapat penurunan kemakmuran yang diterima pemegang saham. Hal tersebut merupakan sinyal buruk (bad news), sehingga 
akan berpengaruh terhadap menurunnya harga saham. Menurunnya harga saham pada akhirnya akan mengakibatkan menurunnya nilai perusahaan. Sejalan dengan hal tersebut, Wijaya \& Budiasih (2018), Oktavani \& Devie (2017), Yuniarti et al. (2017), Astiti \& Damayanthi (2018), Surifah (2017) dan Darmawan et al.(2019) membuktikan bahwa manajemen laba memiliki pengaruh yang negatif pada nilai perusahaan. Hasil penelitian Darmawan et al.(2019) membuktikan bahwa tindakan manajemen laba berpengaruh negatif signifikan terhadap nilai perusahaan. Hal ini menjelaskan bahwa praktik manajemen laba dapat menurunkan nilai perusahaan. Berdasarkan aspek-aspek tersebut, maka didapatkan hipotesis kedua pada penelitian ini adalah sebagai berikut.

$\mathrm{H}_{2}$ : Manajemen laba dengan pola income decreasing berpengaruh negatif pada nilai perusahaandecreasing.

\section{METODE PENELITIAN}

Penelitian ini menggunakan pendekatan kuantitatif dengan desain penelitian asosiatif yaitu suatu penilaian yang dilakukan untuk mencari hubungan antara satu variabel dengan variabel yang lainnya. Penelitian ini menguji pengaruh manajemen laba baik dari income increasing maupun income decreasing terhadap nilai perusahaan. Lokasi penelitian adalah tempat dimana penelitian tersebut dilakukan. Penelitian ini dilakukan pada perusahaan manufaktur yang terdaftar di Bursa Efek Indonesia (BEI) periode 2014-2018. Data dapat diakses melalui situs resmi Bursa Efek Indonesia di alamat website www.idx.co.id. Harga saham perusahaan manufaktur dapat diakses melalui finance.yahoo.com. Objek yang menjadi kajian pada penelitian ini adalah nilai perusahaan yang terpengaruh oleh praktik manajemen laba. Variabel independen pada penelitian ini adalah manajemen laba. Variabel dependen pada penelitian ini adalah nilai perusahaan.

Data kuantitatif dalam penelitian ini adalah laporan keuangan dari perusahaan manufaktur yang terdaftar di Bursa Efek Indonesia tahun 2014-2018. Berdasarkan sumber datanya, data yang digunakan pada penelitian ini adalah data sekunder. Data sekunder adalah data yang diperoleh secara tidak langsung dari objek penelitian, misalnya dari dokumen atau orang lain. Data sekunder dalam penelitian ini berupa laporan keuangan tahunan dan data harga saham perusahaan.

Populasi pada penelitian ini adalah perusahaan manufaktur yang terdaftar dan telah melakukan pelaporan keuangannya di Bursa Efek Indonesia (BEI) periode tahun 2014-2018 yang berjumlah 167 perusahaan. Data pada penelitian ini adalah data sekunder yang diperoleh dari Bursa Efek Indonesia (BEI). Terdapat sebanyak 30 perusahaan manufaktur dari jumlah populasi (167) yang tidak terdaftar di BEI secara berturut-turut selama periode pengamatan 20142018, sehingga sampel yang digunakan adalah 137 perusahaan manufaktur. Dalam penelitian ini, teknik pengambilan sampel yang digunakan adalah purposive sampling dengan kriteria sebagai berikut: 1) Perusahaan pada sektor manufaktur yang terdaftar di BEI untuk periode 2014-2018. 2) Perusahaan yang telah menerbitkan laporan keuangan untuk periode yang berakhir pada 31 Desember selama rentang tahun penelitian (2014-2018). 3) Perusahaan yang telah menyajikan data yang berkaitan dengan variabel-variabel yang akan diteliti pada penelitian ini selama periode 2014-2018. 
Metode pengumpulan data yang digunakan dalam penelitian ini adalah metode observasi non partisipan, yaitu teknik pengumpulan data observasi atau pengamatan dimana peneliti tidak terlibat secara langsung dan hanya sebagai pengamat independen kemudian data dianalisis dengan analisis linear berganda.

\section{HASIL DAN PEMBAHASAN}

Adapun perusahaan manufaktur yang terdaftar di BEI periode 2014-2018 berjumlah 167 perusahaan. Sampel dalam penelitian ini diperoleh dengan teknik purposive sampling atau dengan kriteria tertentu. Penelitian ini menggunakan sampel yang memenuhi kriteria pemilihan sampel yang telah ditentukan sebelumnya. Berdasarkan observasi penelitian yang dilakukan, maka perusahaan yang dapat dijadikan sampel sebanyak 137 perusahaan dengan jumlah data pengamatan selama 5 tahun sebanyak 685 .

Tabel 2. Proses Pemilihan Sampel

\begin{tabular}{|c|c|c|c|c|}
\hline No. & Keterangan & Jumlah & $\begin{array}{c}\text { Pengamatan } \\
\text { Manajemen } \\
\text { Laba Income } \\
\text { Increasing }\end{array}$ & $\begin{array}{c}\text { Pengamatan } \\
\text { Manajemen } \\
\text { Laba Income } \\
\text { Decreasing }\end{array}$ \\
\hline 1. & $\begin{array}{l}\text { Perusahaan manufaktur } \\
\text { yang terdaftar di BEI } \\
\text { tahun 2014-2018. }\end{array}$ & 167 & & \\
\hline 2. & $\begin{array}{l}\text { Perusahaan manufaktur } \\
\text { yang tidak terdaftar di BEI } \\
\text { secara berturut-turut } \\
\text { selama periode } \\
\text { pengamatan 2014-2018. }\end{array}$ & (30) & & \\
\hline \multicolumn{2}{|c|}{ Total Sampel } & 137 & & \\
\hline \multicolumn{2}{|c|}{ Sampel x Data Pengamatan } & 685 & & \\
\hline \multicolumn{2}{|c|}{ Data yang Tidak Digunakan } & (160) & & \\
\hline \multicolumn{2}{|c|}{ Total Pengamatan } & 525 & 472 & 53 \\
\hline \multicolumn{2}{|c|}{ Data Outlier } & & (371) & (0) \\
\hline \multicolumn{2}{|c|}{ Pengamatan Setelah Outlier } & & 101 & 53 \\
\hline
\end{tabular}

Jumlah sampel yang diperoleh dalam penelitian ini adalah sebanyak 137 perusahaan manufaktur dengan jumlah pengamatan sebanyak 685. Terdapat tiga puluh dua (32) perusahaan yang datanya tidak dapat digunakan (selama 5 tahun menjadi 160 data). Hal tersebut disebabkan oleh: Laporan keuangan tahun 2018 dari beberapa perusahaan manufaktur tidak dapat ditemukan dan Beberapa perusahaan merubah tahun buku dari 31 Desember menjadi 31 Maret di tahun berikutnya. Akibatnya data laporan keuangan tidak dapat diperbandingkan.

Jumlah pengamatan sebanyak dari 685 menjadi 525 amatan terbagi menjadi dua kelompok, yaitu 472 pengamatan yang menunjukkan terjadinya manajemen laba dengan pola income increasing dan 53 pengamatan yang menunjukkan terjadinya manajemen laba dengan pola income decreasing. Untuk mendapatkan model yang lolos uji asumsi klasik, peneliti melakukan outlier data sebanyak 371 data pada kelompok manajemen laba dengan pola income increasingyang menyebabkan pengamatan berkurang menjadi 101 pengamatan 
dan pada kelompok manajemen laba dengan pola income decreasing tetap 53 pengamatan karena sudah lolos uji asumsi klasik.

Tabel 3. Hasil Uji Deskriptif Manajemen Laba dengan Pola Income Increasing

\begin{tabular}{lcrrrr}
\hline & $\mathrm{N}$ & Minimum & Maximum & Mean & $\begin{array}{c}\text { Std. } \\
\text { Deviation }\end{array}$ \\
\hline Manj. Laba $\left(\mathrm{X}_{1}\right)$ & 101 &, 0894 &, 1630 &, 127457 &, 0214389 \\
$\begin{array}{l}\text { Nilai Perush } \\
\left(\mathrm{Y}_{1}\right)\end{array}$ & 101 &, 2258 & 1,0692 &, 543914 &, 2116519 \\
$\begin{array}{l}\text { Valid N } \\
\text { (listwise) }\end{array}$ & 101 & & & & \\
\hline
\end{tabular}

Sumber: Data Penelitian, 2019

Variabel manajemen laba dengan pola income increasing $\left(\mathrm{X}_{1}\right)$ menunjukkan pengamatan sebanyak 101 amatan. Pengamatan sebesar 101 ini memiliki nilai minimum sebesar 0,0894 yang dimiliki oleh Tempo Scan Pacific Tbk (TSPC) tahun 2017, yang berarti bahwa perusahaan tersebut terindikasi melakukan manajemen laba dengan meningkatkan laba sebesar 0,0894. Nilai maksimum sebesar 0,1630 yang dimiliki oleh SLJ Global Tbk (SULI) tahun 2018, menunjukkan bahwa perusahaan tersebut terindikasi melakukan manajemen laba dengan menaikkan laba sebesar 0,1630. Nilai mean (rata-rata) sebesar 0,127457 memiliki arti bahwa rata-rata manajemen laba dengan pola income increasing pada sampel amatan penelitian ini adalah sebesar 0,1274. Standar deviasi sebesar 0,0214389 berarti terjadi penyimpangan nilai pada nilai rataratanya sebesar 0,0214 .

Variabel nilai perusahaan increasing $\left(\mathrm{Y}_{1}\right)$ yang dihitung menggunakan Tobin's Q menunjukkan jumlah pengamatan sebanyak 101 amatan. Pengamatan sebesar 101 ini memiliki nilai minimum sebesar 0,2258 dimiliki oleh Champion Pacific Indonesia Tbk (IGAR) tahun 2014, yang berarti bahwa perusahaan tersebut memiliki saham yang dinilai sebesar 0,2258 oleh pasar yang artinya bahwa saham dalam kondisi undervalued atau dapat dikatakan memiliki nilai perusahaan yang rendah, karena nilainya lebih kecil dari 1. Nilai maksimum sebesar 1,0692 yang dimiliki oleh Panasia Indo Resources Tbk (HDTX) tahun 2016 yang berarti bahwa perusahaan tersebut memiliki saham yang dinilai sebesar 1,0692 oleh pasar yang artinya saham dalam kondisi average atau dapat dikatakan memiliki nilai perusahaan sedang atau menengah, karena nilainya hampir mendekati 1. Potensi pertumbuhan investasi saham tersebut tidak berkembang. Nilai rata-rata sebesar 0,543914 berarti bahwa rata-rata nilai perusahaan pada sampel amatan penelitian ini adalah senilai 0,5439. Nilai ratarata 0,5439 yang berada di bawah 1 berarti bahwa biaya penggantian aset atau aset perusahaan lebih tinggi daripada nilai pasar perusahaan, maka saham dalam kondisi undervalued. Standar deviasi sebesar 0,2116519 berarti terjadi penyimpangan nilai pada nilai rata-ratanya sebesar 0,2116.

Variabel manajemen laba dengan pola income decreasing (X2) menunjukkan jumlah pengamatan sebanyak 53 amatan. Pengamatan sebesar 53 ini memiliki nilai minimum sebesar -0,3403 yang dimiliki oleh Primarindo Asia Infrastructure Tbk (BIMA) tahun 2015 yang berarti bahwa perusahaan tersebut terindikasi melakukan manajemen laba dengan menurunkan laba sebesar 0,3403. Nilai maksimum sebesar -0,0034 yang dimiliki oleh Citra Tubindo Tbk 
(CTBN) tahun 2017, menunjukkan bahwa perusahaan tersebut terindikasi melakukan manajemen laba dengan menurunkan laba sebesar -0,0034. Nilai ratarata sebesar -0,060053 menunjukkan bahwa rata-rata manajemen laba dengan pola income decreasing pada sampel amatan penelitian ini adalah sebesar -0,060. Standar deviasi sebesar 0,0603849 memiliki arti bahwa terjadi penyimpangan pada nilai rata-ratanya sebesar 0,060 .

Tabel 4. Hasil Uji Deskriptif Manajemen Laba dengan Pola Income Decreasing

\begin{tabular}{lrrrrr}
\hline & $\mathrm{N}$ & \multicolumn{1}{c}{ Minimum } & Maximum & \multicolumn{1}{c}{ Mean } & Std. Deviation \\
\hline Manj. Laba $\left(\mathrm{X}_{2}\right)$ & 53 &,- 3403 &,- 0034 &,- 060053 &, 0603849 \\
Nilai Perush & 53 &,- 1158 & 3,7256 & 1,082885 & 1,0623665 \\
(Y2) & & & & & \\
Valid N & 53 & & & & \\
(listwise) & & & & & \\
\hline
\end{tabular}

Sumber: Data Penelitian, 2019

Variabel nilai perusahaan decreasing $\left(\mathrm{Y}_{2}\right)$ yang dihitung menggunakan Tobin's Q menunjukkan jumlah pengamatan sebanyak 53 amatan. Pengamatan sebesar 53 ini memiliki nilai minimum sebesar -0,1158 yang dimiliki oleh Unggul Indah Cahaya Tbk (UNIC) tahun 2014 yang berarti bahwa saham tersebut dalam kondisi undervalued serta potensi pertumbuhan investasi rendah. Nilai maksimum sebesar 3,7256 yang dimiliki oleh Asia Pacific Fibers Tbk (POLY) tahun 2014. Hal ini menunjukkan bahwa saham dalam kondisi overvalued. Manajemen berhasil dalam mengelola aktiva perusahaan serta potensi pertumbuhan investasi tinggi. Nilai rata-rata sebesar 1,082885 berarti bahwa ratarata nilai perusahaan pada sampel amatan penelitian ini adalah sebesar 1,083. Nilai rata-rata 1,083 berarti saham dalam kondisi average serta potensi pertumbuhan investasi tidak berkembang karena nilai perusahaan hampir mendekati 1. Standar deviasi sebesar 1,0623665 berarti bahwa terjadi penyimpangan nilai pada nilai rata-ratanya sebesar 1,0624

Tabel 5. Hasil Regresi Linear Manajemen Laba dengan Pola Income increasing

\begin{tabular}{|c|c|c|c|c|c|c|c|}
\hline & \multicolumn{2}{|c|}{$\begin{array}{l}\text { Unstandardized } \\
\text { Coefficients }\end{array}$} & \multirow{2}{*}{$\begin{array}{c}\text { Standardized } \\
\text { Coefficients } \\
\text { Beta }\end{array}$} & \multirow[t]{2}{*}{$t$} & \multirow[t]{2}{*}{ Sig. } & \multicolumn{2}{|c|}{$\begin{array}{c}\text { Collinearity } \\
\text { Statistics }\end{array}$} \\
\hline & B & Std. Error & & & & Tolerance & VIF \\
\hline (Constant) & 0,648 & 0,128 & & 5,074 & 0,000 & & \\
\hline Manj. Laba & $\begin{array}{c}- \\
0,819\end{array}$ & 0,989 & $-0,083$ & $\begin{array}{c}- \\
0,829 \\
\end{array}$ & 0,409 & 1,000 & 1,000 \\
\hline
\end{tabular}

Sumber: Data Penelitian, 2019

Nilai konstanta sebesar 0,648 memiliki arti bahwa ketika variabel manajemen laba sama dengan nol, maka rata-rata nilai perusahaanincreasing $\left(\mathrm{Y}_{1}\right)$ akan meningkat sebesar 0,648 satuan.Nilai koefisien regresi variabel manajemen laba dengan pola income increasing sebesar $-0,819$ memiliki arti bahwa ketika variabel manajemen laba dengan pola income increasing meningkat satu satuan, maka nilai perusahaanincreasingakan menurun sebesar -0,819 satuan

Nilai konstanta sebesar 0,533 memiliki arti bahwa ketika variabel manajemen laba sama dengan nol, maka rata-rata nilai perusahaandecreasing $\left(\mathrm{Y}_{2}\right)$ akan meningkat sebesar 0,533 satuan.Nilai koefisien regresi variabel manajemen laba dengan pola income decreasing sebesar -9,161 memiliki arti bahwa ketika variabel manajemen laba dengan pola income decreasing meningkat satu satuan, maka akan menurunkan nilai perusahaandecreasingsebesar -9,161 satuan. 
Tabel 6. Hasil Regresi Linear Manajemen Laba dengan Pola Income Decreasing

\begin{tabular}{|c|c|c|c|c|c|c|c|}
\hline & \multicolumn{2}{|c|}{$\begin{array}{l}\text { Unstandardized } \\
\text { Coefficients }\end{array}$} & \multirow{2}{*}{$\begin{array}{c}\begin{array}{c}\text { Standardized } \\
\text { Coefficients }\end{array} \\
\text { Beta }\end{array}$} & \multirow[t]{2}{*}{$\mathrm{t}$} & \multirow[t]{2}{*}{ Sig. } & \multicolumn{2}{|c|}{$\begin{array}{c}\text { Collinearity } \\
\text { Statistics }\end{array}$} \\
\hline & B & Std. Error & & & & Tolerance & VIF \\
\hline (Constant) & 0,533 & 0,178 & & 2,989 & 0,004 & & \\
\hline Manj. Laba & $\begin{array}{c}- \\
9,161\end{array}$ & 2,103 & $-0,521$ & $\begin{array}{c}- \\
4,356\end{array}$ & 0,000 & 1,000 & 1,000 \\
\hline
\end{tabular}

Sumber: Data Penelitian, 2019

Kelompok manajemen laba dengan pola income increasing memiliki $\mathrm{R}^{2}$ sebesar 0,007. Hal ini berarti bahwa 0,7\% variasi dari nilai perusahaan yang melakukan manajemen laba dengan pola income increasing dapat dijelaskan oleh variasi variabel manajemen laba dengan pola income increasing. Sedangkan sisanya 99,3\% dijelaskan oleh variabel lain di luar model. Berdasarkan hasil analisis regresi linear sederhana, diperoleh $\mathrm{R}^{2}$ sebesar 0,271 untuk kelompok manajemen laba dengan pola income decreasing. Hal ini berarti bahwa 27,1\% variasi dari nilai perusahaan yang melakukan manajemen laba dengan pola income decreasing dapat dijelaskan oleh variasi variabel manajemen laba dengan pola income decreasing. Sedangkan sisanya $72,9 \%$ dijelaskan oleh variabel lain di luar model

Nilai probabilitas signifikansi ( $\mathrm{p}$-value) untuk variabel manajemen laba dengan pola income increasing sebesar 0,409. Nilai tersebut berada di atas tingkat signifikansi yang ditetapkan, yaitu 0,05. Hal ini berarti hipotesis pertama yang menyatakan bahwa manajemen laba dengan pola income increasing berpengaruh positif pada nilai perusahaan, ditolak $\left(\mathrm{H}_{1}\right.$ tidak dapat diterima).p-value variabel manajemen laba dengan pola income decreasing sebesar 0,000 berada di bawah tingkat signifikansi 0,05 . Hal ini berarti hipotesis kedua yang menyatakan bahwa manajemen laba dengan pola income decreasing berpengaruh negatif pada nilai perusahaan dapat diterima $\left(\mathrm{H}_{2}\right.$ tidak dapat ditolak).

Variabel bebas manajemen laba dengan pola income increasing memiliki pvalue sebesar 0,409 berada di atas tingkat signifikansi 0,05 dengan arah yang negatif $(-0,829)$. Hal ini berarti manajemen laba dengan pola income increasing tidak berpengaruh pada nilai perusahaan atau dapat dikatakan hipotesis pertama ditolak $\left(\mathrm{H}_{1}\right.$ tidak diterima). Hasil penelitian ini tidak sesuai dengan penelitian Subanidja et al.(2016) dan Susanto \& Christiawan (2016) yang membuktikan bahwa manajemen laba memiliki pengaruh yang positif pada nilai perusahaan. Hasil penelitian ini sesuai dengan hasil yang didapat oleh Ustman \& Ghofar (2016), Susanto (2017) dan Sunardi (2018) yang mendapatkan hasil bahwa manajemen laba tidak berpengaruh pada nilai perusahaan.

Pada kondisi tertentu manajemen laba dengan pola income increasing dapat tidak berpengaruh pada nilai perusahaan. Ustman \& Ghofar (2016) menyimpulkan dalam penelitiannya, manajemen laba yang diukur dengan discretionary accrual dapat berpengaruh positif terhadap nilai perusahaan secara tidak signifikan artinya manajemen laba tidak berpengaruh secara signifikan terhadap nilai perusahaan. Mawati et al. (2017) menyatakan, tindakan manajemen laba yang dilakukan tidak akan memberikan reaksi yang berdampak pada peningkatan nilai perusahaan yang tercermin dalam harga sahamnya. Kondisi ini menunjukkan pasar saham atau investor mengabaikan informasi 
rekayasa laba yang menggunakan pola income increasing. Laba yang bersifat opportunistic tidak mewakili informasi yang sebenarnya akan merugikan investor dan juga para stakeholders. Laba yang memiliki kualitas rendah juga akan merugikan perusahaan sebab hal ini berhubungan dengan nilai perusahaan yang tercermin dalam harga saham yang ditransaksikan (Sunardi, 2018). Astiti \& Damayanthi(2018)dalam penelitiannya menyebutkan bahwa investor cenderung menghukum perusahaan yang manajemennya melakukan manajemen laba intensif. Hal tersebut berarti dalam kondisi tertentu ketika investor menemukan bahwa perusahaan terindikasikan melakukan manajemen laba dengan pola income increasing, investor cenderung mengabaikan informasi tersebut sehingga nilai perusahaan terpengaruh secara tidak signifikan.

Pengelola perusahaan lebih banyak mengetahui informasi perusahaan dibandingakan dengan principal sehingga menimbulkan asimetri informasi. Manajer diwajibkan memberikan sinyal mengenai kondisi perusahaan kepada pemilik menggunakan media yang disebut laporan keuangan. Dalam hal ini manajer melakukan praktik manajemen laba agar bisa memberikan sinyal dan berharap akan adanya peningkatkan nilai perusahaan, justru tidak memberikan pengaruh apa pun. Sehingga berdasarkan hasil penelitian, besar kecilnya nilai perusahaan tidak dipengaruhi oleh manajemen laba dengan pola income increasing.

Variabel bebas manajemen laba dengan pola income decreasing memiliki pvalue sebesar 0,000 berada di bawah tingkat signifikansi 0,05 dengan arah negatif $(-4,356)$. Hal ini berarti manajemen laba dengan pola income decreasing berpengaruh negatif pada nilai perusahaan atau dapat dikatakan hipotesis kedua dapat diterima ( $\mathrm{H}_{2}$ tidak dapat ditolak). Hasil penelitian ini sesuai dengan hasil yang didapat oleh Astiti \& Damayanthi (2018) dan Darmawan et al. (2019) yang mendapatkan hasil bahwa manajemen laba berpengaruh negatif ada nilai perusahaan. Astiti \& Damayanthi (2018) menyatakan bahwa ketika manajer melakukan tindakan manajemen laba adalah untuk memenuhi kepentingan pribadinya, maka pemegang saham akan dirugikan oleh tindakan manajer tersebut. Manajemen laba yang mengandung perilaku opportunistic dapat membuat menurunnya harga saham perusahaan. Perilaku manajemen laba dengan menurunkan laba ternyata tidak dilakukan dengan tujuan meningkatkan nilai perusahaan. Hal tersebut juga didukung oleh hasil penelitian yang dilakukan oleh Darmawan et al. (2019) yang menyatakan bahwa tindakan manajemen laba dapat menurunkan nilai perusahaan.

Informasi laba sebagai hasil dari tindakan manajemen laba yang dilakukan dengan menurunkan laba merupakan sinyal negatif yang direspon oleh pasar sebagai bad news, sehingga akan berdampak pada menurunnya harga saham perusahaan. Menurunnya harga saham akan membuat menurunnya nilai perusahaan dan berdampak pada menurunnya kemakmuran yang akan diterima oleh pemegang saham. Praktik manajemen laba yang mengandung perilaku opportunistic tersebut dinilai dapat menurunkan kepercayaan masyarakat terhadap perusahaan sehingga berdampak pada penurunan nilai perusahaan. Penelitian ini dapat memberikan kontribusi mengenai pengaruh manajemen laba pada nilai perusahaan di perusahaan manufaktur yang terdaftar di BEI periode 2014-2018. Hasil pengujian regresi linear sederhana menemukan 
bahwa variabel bebas berpengaruh pada variabel terikat nilai perusahaan sehingga hasil penelitian ini mampu membuktikan secara empiris teori keagenan dan teori sinyal.

Penelitian ini dapat memberikan kontribusi bagi semua pihak khususnya pihak investor. Tindakan manajemen laba akan berdampak negatif kepada investor karena merasa dirugikan atas informasi yang tidak sesuai dengan kinerja perusahaan, tentu investor akan mempertimbankan kembali untuk berinvestasi di perusahaan tersebut. Bagi investor atau pihak berkepentingan diharapkan dapat menganalisis lebih baik atas laporan keuangan yang dilaporkan. Para investor maupun para calon investor dalam membuat keputusan sebaiknya tidak melihat sebatas hanya pada informasi laba, tetapi diikuti pula dengan melihat informasi fundamental perusahaan seperti hasil analisa pada arus kas serta rasio-rasio keuangan.

\section{SIMPULAN}

Manajemen laba dengan pola income increasing tidak berpengaruh pada nilai perusahaan. Hal ini disebabkan karena manajemen laba yang dilakukan tidak akan memberikan reaksi yang berdampak pada peningkatan nilai perusahaan yang tercermin dalam harga sahamnya. Sebab, investor cenderung mengabaikan informasi laba yang dipengaruhi oleh praktik manajemen laba dengan pola income increasing, karena laba yang bersifat opportunistic tidak mewakili informasi yang sebenarnya akan merugikan investor dan juga para stakeholders. Manajemen laba dengan pola income decreasing berpengaruh negatif pada nilai perusahaan. Hal ini disebabkan karena informasi penurunan laba mengandung perilaku opportunistic yang dapat merugikan pemegang saham, sehingga pasar merespon informasi tersebut sebagai bad news yang menyebabkan menurunnya harga saham perusahaan yang berdampak pada menurunnya nilai perusahaan. Menurunnya nilai perusahaan berarti kemakmuran pemegang saham juga menurun. Manajemen laba income increasing yang cenderung tidak memberikan reaksi pasar dan manajemen laba income decreasing yang cenderung direspon negatif oleh pasar menunjukkan bahwa bad news lebih cepat direspon negatif oleh pasar dibandingkan good news atau informasi laba yang meningkat.

Praktik manajemen laba yang terdorong oleh tujuan efficiency maupun perilaku opportunistic sebenarnya akan mengurangi kualitas laba yang dilaporkan. Maka dari itu, para investor diharapkan tidak hanya berpegang teguh pada informasi laba, tetapi juga harus mempertimbangkan arus kas dan faktor-faktor lain dengan menggunakan analisis rasio-rasio keuangan. Penelitian ini hanya dibatasi pada perusahaan manufaktur yang terdaftar di Bursa Efek Indonesia periode 2014-2018, sehingga hasil penelitian ini tidak dapat digeneralisasi pada seluruh jenis perusahaan. Penelitian berikutnya disarankan untuk memperluas wilayah penelitian, yaitu dengan mengikutsertakan seluruh jenis perusahaan yang terdaftar di Bursa Efek Indonesia. 


\section{REFERENSI}

Abbas, A. (2018). Earnings Management in Banking Industry And Its Impact on The Firm Value. Research Gate, 10(1), 69. https://doi.org/10.26740/jaj.v10n1.p69-84

Astiti, N. P. S., \& Damayanthi, I. G. A. E. (2018). Pengaruh Manajemen Laba pada Nilai Perusahaan Sesudah Pergantian Chief Executive Officer (CEO). EJurnal Akuntansi, 23(1), 185-210.

Dalimunthe, A. R. (2016). Pengaruh Corporate Social Responbility, Persistensi Laba, Dan Struktur Modal Terhadap Earnings Response Coefficient. Jurnal Wahana Akuntansi, 11(1),

1. https://doi.org/10.21009/10.21.009/wahana.011/1.1

Darmawan, I. P. E., Sutrisno, T., \& Mardiati, E. (2019). Accrual Earnings Management and Real Earnings Management: Increase or Destroy Firm Value? International Journal of Multicultural and Multireligious Understanding, 6(2), 8. https://doi.org/10.18415/ijmmu.v6i2.551

Fahmi, M., \& Prayoga, M. D. (2018). Pengaruh Manajemen Laba terhadap Nilai Perusahaan dengan Tax Avoidance sebagai Variabel Mediating. Liabilities (Jurnal Pendidikan Akuntansi), 1(3), 225-238. https://doi.org/10.30596/liabilities.v1i3.2496

Ghazali, A. W., Shafie, N. A., \& Sanusi, Z. M. (2015). Earnings Management: An Analysis of Opportunistic Behaviour, Monitoring Mechanism and Financial Distress. Procedia Economics and Finance, 28(April), 190-201. https://doi.org/10.1016/s2212-5671(15)01100-4

Gill, A., Biger, N., Mand, H. S., \& Mathur, N. (2015). Earnings Management, Firm Performance, and the Value of Indian Manufacturing Firms. International Research Journal of Finance and Economics, 116(12), 1-14. Retrieved from http://www.internationalresearchjournaloffinanceandeconomics.com

Ježovita, A. (2015). Accounting Information in a Business Decision-Making Process - Evidence from Croatia. Zagreb International Review of Economics and Business, 18(1), 61-79. https:/ / doi.org/10.1515/zireb-2015-0004

Kanakriyah, R., Shanikat, M. M., \& Freihat Abdel Razaq. (2017). Exploitation of Earnings Management Concept to Influence the Quality of Accounting Information: Evidence from Jordan. Research Journal of Finance and Accounting, 8(22), 53-65. Retrieved from www.iiste.org

Lesmana, I. P. A. S., \& Sukartha, I. M. (2017). Pengaruh Manajemen Laba Pada Nilai Perusahaan Manufaktur Yang Terdaftar Di Bursa Efek Indonesia Tahun 2012-2015. E-Jurnal Akuntansi Universitas Udayana, 19(2), 1060-1087.

Mawati, E. R., Hardiningsih, P., \& Srimindarti, C. (2017). Corporate Governance Memoderasi Earnings Management. Jurnal Akuntansi, 1(1), 519-528.

Nursya'adah, D. (2020). Analisis Kemampuan Prediktif Laba Kotor, Laba Operasi, Laba Bersih, Arus Kas Operasi, Perubahan Hutang, Perubahan Piutang, Perubahan Persediaan Dan Perubahan Beban Depresiasi Terhadap Arus Kas Operasi Masa Depan (Studi Empiris pada Perusahaan subsektor pr. Prisma (Platform Riset Mahasiswa Akuntansi), 1(1), 120-135. Retrieved from https://ojs.stiesa.ac.id/index.php/prisma

Oktavani, S., \& Devie. (2017). Effect of Earnings Management on Firm Value through Financial Performance as an intervening variable in companies 
listed in LQ 45. Business Accounting Review, 5(2), 25-34.

Panda, B., \& Leepsa, N. M. (2017). Agency theory: Review of theory and evidence on problems and perspectives. Indian Journal of Corporate Governance, 10(1), 74-95. https:// doi.org/10.1177/0974686217701467

Puspitaningtyas, Z. (2017). Is Financial Performance Reflected in Stock Prices? Advances in Economics, Business and Management Research, 40(1), 17-28. https://doi.org/10.2991/icame-17.2017.2

Rahayu, M., \& Sari, B. (2018). Faktor-Faktor Yang Mempengaruhi Nilai Perusahaan. Jurnal Analisis Bisnis Ekonomi, 16(1), 19-25. https://doi.org/10.31603/bisnisekonomi.v16i1.2127

Sintyana, I. P. H., \& Artini, L. G. S. (2018). Pengaruh Profitabilitas, Struktur Modal, Ukuran Perusahaan Dan Kebijakan Dividen Terhadap Nilai Perusahaan. E-Jurnal Manajemen Universitas Udayana, 8(2), 757. https://doi.org/10.24843/ ejmunud.2019.v08.i02.p07

Subanidja, S., Rajasa, A., Suharto, E., \& Atmanto, J. D. (2016). The determinants of firm value: The role of earnings management and good corporate governance. Corporate Ownership and Control, 13(4), 609-615. https://doi.org/10.22495/cocv13i4c4p10

Suhadak, K., Handayani, S. R., \& Rahayu, S. M. (2019). Stock return and financial performance as moderation variable in influence of good corporate governance towards corporate value. Asian Journal of Accounting Research, 1(1), 1-20.

Sunardi. (2018). The Effect of Earnings Management on Firm Value before and When IFRS Implementation, Modereted Life Cycle Company. Journal of Business and Economics, 9(3), 275-285. https://doi.org/10.15341/jbe(21557950)/03.09.2018/006

Surifah, S. (2017). The Role of Corporate Governance in the Effect Earnings Management Has on Firm Value. Journal of Indonesian Economy and Business, $1(1), 1-20$.

Susanto, S., \& Christiawan, Y. J. (2016). Effect of Earnings Management towards Firm Value. Business Accounting Review, 4(1), 205-216.

Susanto, Y. K. (2017). Accrual earnings management, real earnings management, firm value. International Journal of Business, Economics and Law, 14(1), 1-6. Retrieved from http://ijbel.com/wp-content/uploads/2018/01/ACC-2.pdf

Ustman, S., \& Ghofar, A. (2016). Analisis Pengaruh Manajemen Laba terhadap Nilai Perusahaan Sebelum dan Saat Implementasi Ifrs. Neo-Bis, 10(1), 49-61.

Wijaya, D. S., \& Budiasih, I. G. A. N. (2018). Manajemen Laba Terhadap Nilai Perusahaan Pada Pergantian CEO. Research Gate, 1(1), 1-20.

Yuniarti, E., Mukhtaruddin, \& Hanim, N. (2017). Effect on Value earnings management company with Good corporate governance practices as moderating variable. SHS Web of Conferences, 34(1), 1-7. https://doi.org/10.1051/ 73404007 